\title{
The Availability of Reliable Information About Medicines in Serbia for Health Professionals
}

\section{Summary of Product Characteristics}

\author{
Ljiljana C. Djukić́, Branka M. Terzić \\ ${ }^{1}$ Medicines and Medical Devices Agency of Serbia - ALIMS, Belgrade, Serbia \\ ${ }^{2}$ Clinical Center of Serbia, Belgrade, Serbia
}

\begin{abstract}
SUMMARY
Introduction Today, there are many drugs for the treatment of a large number of indicator areas. Significant financial resources are invested in research with the aim of introducing reliable therapeutics to therapy. Therefore, it is necessary to provide health care professionals exact information about new therapies.

The overall process of scientific data, ideas and information exchange is possible through numerous communications of modern IT tools.

Methodology According to the Law, key information on registered drug is included in the Summary of Product Characteristics (SPC) for health professionals, which is harmonized with EU directives and regulations (SmPC). Protocol content and structure of the information provided in SPC is determined in the guidelines of the EU, therefore, a unique set of data is established for all the drugs registered in Serbia.

Topic This paper presents the key segments of SPC, with special reference to the description of the regulations that are required for data related to indications, mechanism of action, dosage, contraindications, side effects, interactions and other important information regarding the profile of the drug, which are standardized and harmonized with the structure of identical documents which operate at the EU level, or EMEA.

Conclusions SPC is the regulatory determined technical document on medicinal products in the RS in which there are listed scientifically proven, clinical and pharmacological data and information on the profile of the drug, which are essential for health professionals - doctors and pharmacists in the implementation of pharmacotherapy in our society. This document is the starting point for the development of applied Pharmacoinformatics and it includes a range of activities important for the development of appropriate manuals and makes available data and information for monitoring indicators of the national policy on drugs and modern effective drugs treatment.
\end{abstract}

Keywords: Drugs, Summary of Product Characteristics, ALIMS 


\section{INTRODUCTION}

A large number of data and information daily gained in all areas of healthcarerequire the establishment of an efficient and reliable system that provides exact information important for health care.The availability of reliable and objective information on drugs is of great importance for the implementation of rational, evidence- based pharmacotherapy [1]. Modern information technology are conquering the world, because in the modern business conditions, it is impossible to plan without an effective information system, run a successful business and manage changes if there are no information directly usable for specific decisions.

\section{METHODOLOGY}

Holders of information are documents presented in diverse media: internet, knowledge bases, scientific biomedical informatics, international documents, the original files on the product, regulatory documents, regulations, laws and other related regulations [2]. In an era of intensive use of computer technology and powerful software tools, is being established unique communication language of unambiguous designation factors and processes that allow an easier and more reliable access to relevant information and the exchange of information for everyday work, but also for scientific and research activities. The primary sources of data are in the primary publications or documents that contain texts with primary information in its original form, and may be the original texts of regulatory authorities and authors and are valuable sources of information [3]. Secondary data sources are contained in secondary publications whose content refers to primary sources (indexing journals, general and special bibliographies, manuals, library catalogs, etc.) [4].

\section{TOPIC}

When it comes to drugs or, more broadly, medical products reliable regulatory base with a central database on medicinal products, a unique classification (ATC) and identification (EAN code for each drug) providing a reliable and good practice standards for medical and pharmaceutical information provides reliable source for rational therapy [5]. Information about medicines may include: providing basic, brief information on the safe and proper use of the drug, the answer to the questions related to the provision of detailed information suitable for patients, "Patient-user training on the product(s)," during which provide comprehensive information on the proper use of the drug, as well as through an interactive process of communication physicians or pharmacists who contribute to the improvement of health care. Information for healthcare professionals are contained in the summary of product characteristics (SPC), which approves the procedure of registration of medicinal products and provides essential information on the medicine necessary for health professionals. The same is over time remodeled by means of socalled variations that provide new safety information on the profile of a given [6].

Safe pharmacotherapy includes: genuine drug of high quality, for a defined diagnosis in adequate dosage and for a sufficient time for the individual user. In order to create the conditions for a unique labeling, traceability of the drug to the end user, today we can be satisfied that the conditions are provided for achieving the goal of "accompaniment track", by establishing a system of GS1 standards in the labeling of medicines. European Article Numbering International Association (EAN) system provides a unique identification system in the international arena [7]. International code, or system of recognizable label, applied to any drug, gives the product a unique identification for adequate product, uniquely and unambiguously regardless of the country and place of its origin or purpose, wherever they occur in the world.

Safety of patients: The Law on Medicines and Medical Devices (Official gazette. RS, No. $84 / 2004$; No. $30 / 10$ and $107 / 2012$ ) states that the ready-made drug is "a drug marketedin a certain intensity, form and packageunder the brand name or international name. Readymade drug under special trade name of the manufacturer is marked, dispensed or sold as a drug with the brand name. Ready medication can be dispensed or marketed under the INN, which is defined by the WHO, with the name of the manufacturer. Regulatory established types of drugs are: biological medicine (article 15 ), the immune drug (article 16), drugs for advanced therapy (article 17), medicines from blood and plasma (article 18), radiopharmaceuticals (article 19), a herbal remedy (article 
20), traditional medicine and traditional herbal remedy (article 21), a homeopathic remedy (article 22), drugs for which the license is not required (article 39) [8]. The law in article 46 provides that: In the procedure of issuing permits for marketing authorization determines the regime of drugs dispensed, including: prescription drugs and medicines without a prescription. Drugs that have low toxicity, high therapeutic range, safety in overdose, minimal interaction, whose indications are well known to the patient-the user and used for self-medication are issued in pharmacies without a prescription. Drugs that contain narcotics or psychogenic substances in accordance with international conventions in this field are issued in accordance with the specific regime determined in their marketing authorization (RP in duplicate) [9]. The traditional homeopathic medicines whose regime of issuance is without a prescription are issued/sold in pharmacies. Medication can't be dispensed or sold contrary to the conditions and mode of issuing medicines determined in their marketing authorization.

The key document as an integral part of the drug's summary of product characteristics (SPC). Article 8 (3) (j) of Directive 2001/83/EC and article 6 (1) of Regulation (EC) 726/2004), require that in order to obtain authorization for a medicinal product, the Summary of Product Characteristics drugSPC) in accordance with article 11 of Directive 2001/83/EC must be also included. In accordance with article 21 of Directive 2001/83/EC, when issued permits for marketing authorization, the holder of the marketing authorization shall be notified by the competent authorities of the Member States to which it relates, that they approve of the SPC. For decisions relating to the centralized procedure for marketing authorization, in accordance with article 10 of Regulation (EC) No. 726/2004, the final decision of the Commission and approved SPC indicate the Holder of the marketing authorization. The law in article 2 gives definitions of terms that are standardized as follows: 52 Summary of product characteristics (SPC) is a manufacturer of document which contains basic information about the medicinal product and is part of the documentation required to obtain a license for the drug. In addition, the Regulations on the content of the request and documentation, as well as the method of obtaining a marketing authorization (Official Ga- zette of RS no. 30/2012) In article 3 states that: integral part of the drug SPC, the user drug and text for inner and outer packaging $[10,11]$. In Art.14 lists all required parts of files to cure as follows: Proposal SPC, the draft guidelines for the drug, the draft packaging (mock- up), the draft text of outer and inner packaging (labeling). A copy of the printed original packaging and instructions, SPC are approved in other countries (EU and other countries that have the same or similar requirements for a license). Proposal SPC is published in Serbian language (article 15) and complies with the technical terms used in the Republic of Serbia. Such accepted content of the SPC may not be changed except with the approval of the competent institution and it is approved. SPC proposal may contain information on medicines with the same active ingredient and the same brand name or generally accepted name for a trademark or manufacturer's name in different strengths and packages. When there is a guide for making SPC for a specific therapeutic group (antibiotics), pharmacological group (benzodiazepines), or the type of drug products (vaccines), this guide is used for making SPC. The European Commission and some Member States require a separate SPC for each pharmaceutical form and strength of the drug and accordingly some foreign drugs in RS have separate SPC. Information for patients-users is compiled in accordance with the content of SPC.

Summary of product characteristics [12] contains the following information:

- Product name, form, strength and packaging;

- Manufacturer and Address;

- Applicant and Address;

1. NAME OF MEDICINE, international nonproprietary name (INN);

2. QUALITATIVE AND QUANTITATIVE COMPOSITION;

3. PHARMACEUTICAL FORM;

4. CLINICAL DATA:

4.1. Therapeutic indications;

4.2. Dosage and method of administration;

4.3. Contraindications;

4.4. Special warnings and precautions for use of the drug;

4.5. Interaction with other medicinal products and other forms of interaction;

4.6. Use in pregnancy and lactation;

4.7. Effects on ability to drive and use machines; 
4.8. Side effects;

4.9. Overdose;

5. PHARMACOLOGICAL DATA:

5.1. Pharmacodynamic

Pharmacotherapeutic group: ATC code;

5.2. The pharmacokinetic data;

5.3. Preclinical data on drug safety;

6. PHARMACEUTICAL DATA:

6.1. List of excipients;

6.2. Incompatibility;

6.3. Expiration date;

6.4. Special precautions for storage;

6.5. Nature and contents of container;

6.6. Special precautions for disposal of materials to be disposed of after drug administration;

7. The permit holder;

8. NUMBER OF PERMITS AND FIRST RENEWAL

9. DATE OF THE FIRST AND DATE OF PERMIT RENEWAL

10. DATE OF REVISION OF THE TEXT KEY INFORMATION FROM SUMMARY OF PRODUCT CHARACTERISTICS

NAME OF MEDICINE (Invented) name, (strength and pharmaceutical form) include: International Non-proprietary Name (INN) or the common name of the active substance [13]; the strength of the drug indicates the amount of active substance, which is important for the identification and use of the drug and is consistent with the amount stated in the quantitative composition and dosage of the drug [14]. Notefor Guidance on Quality of Herbal Medicinal Products is used as the guide to express the names and strength of (traditional) herbal medicines.

1. QUALITATIVE AND QUANTITATIVE COMPOSITION provides active content (INN) and auxiliary substances (which have confirmed the fact) in Serbian language. For (traditional) herbal medicine, the declaration of composition quality is in accordance with Note for Guidance on Quality of Herbal Medicinal Products. For radiopharmaceutical kit, declaration of qualitative composition clearly states that radioisotope does not belong to that set. Quantitative composition according to the content of the active substance or strength of the drug is expressed as: individual per unit dosage form; per unit volume, if it is in accordance with the pharmaceutical form; per unit mass, if it is in accordance with the pharmaceutical form. The active substance in the form of compounds (e.g., in the form of a salt or es- ter) is expressed as the amount of the active form, with the INN or generic name. In Part of quantitative composition is stated whether drugs are: salt hydrates, esters and pro-drugs, oral powders for solution or suspension, parenteral dosage forms except powders for reconstitution, powders for reconstitution prior to parenteral administration, concentrates, transdermal patches, multi dose solid or semisolid preparations, biological medicines, herbal remedies.

2. PHARMACEUTICAL FORM is defined according to European Pharmacopeia using full standard term, in that by means of technological processes is incorporated the active ingredient and thus allows its use, taking into account the physiological conditions of the body and the physicochemical properties of the substance, and may be: the final oral pharmaceutical form which is a form of the drug that patient receives (e.g., suspensions); Basic pharmaceutical form of the drug, which is a form in which the drug manufacturer puts medicine on the market (e. g . a powder for suspension). Additional information may be specified, such as pills "dividing line serves only to facilitate swallowing and not to divide into equal doses "or" pill can be divided into equal halves."

\section{CLINICAL DATA}

Therapeutic indications (4.1) In SPC the indications are stated clearly and concisely (target disease or condition), with distinction for therapeutic use (symptomatic, curative or that modifies the evolution or progression of the disease), preventive treatment (primary or secondary) and diagnostic treatment. When appropriate, the target population is defined, especially when applied restrictions for certain patient populations. Where drug is indicated in a specific age group, (adolescents), age is stated for the specific indication [15].

Dosage and method of administration (4.2): The dose is clearly defined for each method of application and for each indication, according to the Note for Guidance on Clinical Investigation of Medicinal Products in Children (CPMP/EWP/462/95), foradult and elderly patients, and includes: the maximum recommended dose (single, daily and/or the total), the need for dose titration, the normal duration of therapy and any length limitation of drug administration and, if necessary, the need to gradually reduce the dose to the abolition, or provides advices regarding discontinuation of therapy, advice on what to do if you miss one 
or more doses, advice on preventive measures to be taken to avoid some adverse drug reactions (ADR) (e.g. administrating antiemetics), then taking the drug in relation to food intake, advice relating to the repeated application with information on intervals to be followed for the amendment of certain cycles of treatment and interactions that require specific adjustment of dosage. Here are the statements and additional information on special populations related to: dose adjustment is necessary for specific groups of patients, renal insufficiency (distinguishing the degree of damage), and liver failure (cirrhosis associated with alcohol use), Child-Pugh score/status of patients and other concomitant diseases. For pediatric patients the dose is reflected on body weight or body surface area. If a pediatric formulation is not approved it leads to the following: "Not recommended for use in children $<$ above $><$ below $>$ Y age due to $<$ lack $><$ insufficient $>$ data on safety and/or efficacy of the stated age."

Then the following information is given:

- Experience in the application of the drug in children is limited, or "There is no experience in the application of the drug in children";

- "There is no relevant indication for use in children";

- "The use of the drug is contraindicated in children";

If the "adult formulation" includes the indication and dosing in children, or just a recommendation for dosing in children, and when appropriate pediatric formulations cannot be developed, additional information is given.

In this section are listed also instructions for product handling, for doctors, other health care personnel and the patient, as well as general information relating to drug application (whether it is applied by the patient himself or by a health worker) which is particularly important for high Differential medication. Part contraindications (4.3) contains data on drugs that should not be used at the same time, data on hypersensitivity to any of the excipients or residues from the manufacturing process, as well as any contraindication arising from the presence of certain excipients of drug (Guideline on excipients in the label and package leaflet of medicinal products for human use). In herbal medicines hypersensitivity is extended to other plants of the same family or other parts of the same plant and is referred to as a contraindication. For special caution and measures (4.4) in the application of the drug are given important information for each drug and to: the conditions under which use of the drug could be acceptable provided that special conditions for use are fulfilled; specific groups of patients (elderly and children) in which are likely to exhibit adverse reactions to a particular drug or group of drugs (under normal conditions of use), the use in patients with renal, hepatic (degree of damage-mild, moderate or severe) or heart failure (NYHA classification); serious adverse reactions (ADR) that the prescriber of medicine must know, the situation in which this may occur, as well as measures that may be necessary; When the outcome of an ADR is particularly serious and/or it is expressed often, it was pointed out if there are special risks associated with the introduction of the medicinal product (first dose effects) or stopping it (e.g., rebound, withdrawal syndrome); all measures that can be taken to identify risky patients and prevent the occurrence of ADR or detect early start or worsening of adverse conditions; Clinically significant interactions are listed where in general the use of the combination should be avoided as well as all the notices that are necessary for accessory or residual matter from the manufacturing process. In the case of immunological products are given any special precautions that should be undertaken by a person who handles such products and delivering them to patients, together with the precautions that should be undertaken by the patient himself. Where necessary, specific interaction with the biological tests are mentioned (Coombs' test, and betalactam test). Warnings and precautions related to pregnancy and lactation, ability to drive and use machines are also mentioned. Part Interaction with other medicinal products and other forms of interaction (4.5) gives information about the potential for clinically significant interactions based on the pharmacodynamic properties and in vivo pharmacokinetic studies of the drug, with special emphasis on the interactions why recommendations are made regarding the use of the drug as follows: all clinical manifestations and effects on plasma concentrations; in relation to the mechanism of the interaction; duration of interaction when a medicinal product is not used with clinically significant interactions (enzyme inhibitor or inducer); Interactions with herbal products, food or other pharmacologically active substances which are not used for medical purposes; pharmacodynamic interactions, 
in which there is the possibility of clinically significant potentiation or a harmful additive effects; If there is a group of patients with the more severe interactions, or interactions are expected to be more indicative (with impaired renal function, pediatric patients, the elderly, children). Application of the drug during pregnancy and lactation (4.6) includes a segment where SKL were given extensive and reliable information labelled as ADR reported in the embryo, fetus, infant and pregnant women, as well as clinical experience in the application of the drug during pregnancy if it has been established. Chapter Impact of the drug on ability to drive and use machines (4.7) provides information whether the medicinal product has no or negligible influence, minor or moderate influence, a significant impact on these abilities which is further defined as:

$\$$ - narcotic drugs (prescription required in duplicate, record keeping of prescription and dispensing; Rx duplicate shall be marked "copy")

$\triangle$ - Empty triangle in the color of the text: the relative ban on driving motor vehicles or machines;

$\Delta$ - full red triangle: the absolute prohibition of driving a motor vehicle or machinery; (Article 83. Regulation on the contents and labeling of external and internal packaging of medicines, as well as the content of the instructions for the drug („Official Gazette of RS, ।” No. 41/2011 of 10.06.2011)

Newly registered drugs have recently established additional labelling:

$\boldsymbol{\nabla}$ - The drug is under additional monitoring. This facilitates the quick detection of new safety information. Healthcare professionals should report any suspected adverse reactions to the drug.

S. Radiopharmaceutical drug (RS already has a registered drugs in this ATC groupV10XA)

Adverse Drug Reactions (4.8) are in SPC defined according to international terminology and EMA requirements, according to the classification system MedDRA, frequency and grade of gravity. Classification of frequency is performed in such a way that the categories of adverse reactions are defined according to the absolute frequency of occurrence based on clinical trial data as:

Very frequent $\geq 1 / 10$

Frequent $\geq 1 / 100$ to $<1 / 10$

Occasional $\geq 1 / 1,000$ to $<1 / 100$

Rare $\geq 1 / 10,000$ to $<1 / 1,000$
Very rare $<1 / 10,000$

Not known (cannot be estimated from available data)

Chapter Overdose (4.9) describes the symptoms and signs and potential effects of different dose levels of the drug, based on random errors and suicide attempts by patients.

PHARMACOLOGICAL DATA (5) segmentmakes an important part essential for assessing the profile of the drug which includes: Pharmacodynamic data (5.1), respectively:

- Pharmacotherapeutic group (ATC Code).

- Mechanism of action

- Pharmacodynamic effects

- Clinical efficacy and safety

When it comes to medical products or drugs, until 2002, our country was the area of drugs and their classification and identification was done according to the UniformSystem of Classification (USC) with effect from January 1, 1986 (Fig. Gazette no.47/85) [13,14]. This was determined by the classification of sorted medicines in 19 therapeutic groups, where each group included several subgroups. However, over time there was a need for harmonization of identification data on drugs at the international level to ensure conditions for unambiguous identification of medicinal products irrespective of the commercial name (brand name drug). This was achieved by Anatomical Therapeutic Chemical classification of drugs (ATC), which is accepted in the international framework for a comprehensive understanding of pharmaceutical and pharmacotherapy developments in one country because drugs are classified according to the INN (International Non-proprietary Name) so that it is possible to monitor them irrespective to the manufacturer, pharmaceutical form, strength, brand name [16]. The concept of the ATC classification is based on the code of 7 mixed alphanumeric characters denoting each INN (generic name), or combined with drugs, each drug combination [17]. These 7 characters give five $[18,19]$ levels of classification as follows: - The first level (anatomical) denotes the capital letter. Drugs are classified into 14 major groups, according to the organic system where primarily exert their effect.

- The second level of two Arabic numbers marks the main therapeutic group to which administered medicine belongs.

- The third level loosely determines the Therapeutic pharmacological subgroup and is marked by a Latin letter. 
- The fourth level is marked with the letter that indicates the pharmaco- chemical subgroup. - The last two Arabic numerals are indicated by the fifth (chemical) level, or identify INN. EXAMPLE [20]:

$\mathrm{N}$ medicaments in the treatment of CNS N02 analgesics

N02B analgesics and antipyretics N02BA salicylic acid derivatives N02BA01 acetylsalicylic acid N02BA11 diflunisal

N02BA.. Lysine acetylsalicylate N02BA51 acetylsalicylic acid, ascorbic acid

N02BB pyrazolone derivatives

N02BE anilides

N02BG other analgesics and antipyretics

5.2 Pharmacokinetic data include information on:

- Resorption stating: complete or incomplete absorption; absolute and/or relative bioavailability; first pass effect; T max; impact of food; in the case of a drug that is administered locally-systemic bioavailability.

- Distribution: plasma protein binding; volume of distribution; tissue and/or plasma; whether the kinetics of the drug in the body describes a multi-space model.

- Biotransformation: the level (volume) of metabolism; which are metabolites; activity of the metabolite; enzymes involved in the metabolism; site of metabolism; Results of in vitro interaction which indicate whether the drug may induce/inhibit metabolic enzymes.

- Elimination: elimination half-life; total clearance; inter-and/or intra-individual variability in total clearance; excretion of unchanged drug and metabolites.

- Linearity/nonlinearity: linearity/non-linearity of the pharmacokinetics of the drug in terms of dose and/or time; if the pharmacokinetics are linear, state the reasons for the lack of linearity.

Preclinical data on the safety of the drug (5.3) give details of: preclinical data obtained based on conventional studies of pharmacology safety, repeated dose toxicity, genotoxicity, carcinogenic potential and reproductive toxicity; Adverse effects were observed in preclinical studies only at doses considered sufficiently in excess of max doze applied in humans and, therefore, have little relevance to the clinical use of the drug; Adverse reactions that are not observed in clinical studies but are observed in studies on animals at doses similar to those that apply in humans and, therefore, may be important for the clinical use of the drug.

6 PHARMACEUTICAL DATA which are very important for the availability of the drug to the site of action include the following information in detail:

6.1 List of excipients states excipients according to their recommended INN, in addition of salt form or hydrate form if it is significant or named in the European Pharmacopoeia. If excipient has no INN, nor pharmacopoeial name, commonly used name is stated.

The number of $\mathrm{E}$ is specified, when it exists and when the excipient is listed in the Guideline on excipients in the label and package leaflet of medicinal products for human use (if there is a recognized action or effect), with the common name of excipients.

6.2 Incompatibilityis the part that contains information about the physical and chemical incompatibilities of the drug with other products with which they are likely to be mixed or administered simultaneously. This is particularly important for drugs to be reconstituted and/or diluted before parenteral administration.

6.3 The part where the information is given to the Expiration date must have information about the expiration date of the drug packaged for sale, with expiry date (month and year) without spelling acronym, noting ।"valid through: month and year|", which means that the drug can be used up to the last day of that month. An important notice of the use of the drug after dilution or dilution is also mentioned and if necessary after first opening the container.

If the drug is not stable at temperatures up to $30^{\circ} \mathrm{C}$, the drug storage temperature is mentioned (e.g. To keep the temp. below $25^{\circ} \mathrm{C}$; keep the temp. $2-8^{\circ} \mathrm{C}$ in the refrigerator; keep in the freezer, or a warning that the drug is not or must not freeze).

6.4 Special warnings and measures for drug storage Special warnings contain one or more standard sentences of Note for Guidance on declaration of storage conditions and the product information of medicinal products for storage of sterile products that have been opened, diluted or reconstituted.

Important parts of SPC are: Nature and contents of container (6.5) and part of the Special precautions for disposal of materials to be disposed of after drug administration (6.6) where are listed all the instructions that are necessary 
for accurate preparation of the drug (cytotoxic, biological drugs) and/or which are necessary for the protection of persons who prepare the medicine or handle it. Here you can find information on the compatibility of the product with other drugs or agents, detailed instructions for the preparation and quality control formulations prepared ex tempore of the appropriate "dosage for adults", as well as additional information for extemporaneous formulations to be applied in children and, where necessary according to max time of storage during which the preparation conform to its specifications. If instructions are necessary for use/handling and when the drug has to be prepared before use, when suspension or dilution must be prepared, the instructions are given in this section.Important SPC parts which cite "origin" of the drug are:

7. The holder of the marketing authorization

8. Number (s) license (s) for marketing authorization

9. Date of first authorization/renewal of the authorization for a medicinal product marketing:In the process of marketing it may be decided on approval "for a period of less than five years". This means that it is a conditional permit for marketing which means waiting for further evidence on the medicinal product, particularly information that should confirm efficiency. ALIMS, based on the available data is certainly required to consider new information on the product at least once a year and,if necessary, update the SPC. For drugs that are approved under conditional approval by centralized procedure is stated that the medication was approved by the procedure of approval "under certain conditions". For drugs that are approved under exceptional circumstances, data is included on whether the drug is registered for rare diseases, for scientific reasons, ethical reasons, because of the impossibility of obtaining complete information on the medicine and other important information that provide specific information about the status the drug.

10. Date of revision of the SPC text contains key information on whether it is in the original SPC language of the country in which the license is issued for a cure or a translation certified by a court interpreter; if there is a difference between the original text and SPC proposal, proposer must designate and explain the differences.

11. Dosimetry is a particularly important part when it comes to radiopharmaceutical preparations, which are given full details of internal radiation dosimetry.

12. Instructions for the preparation of radiopharmaceutical preparation contain and cite detailed instructions on the preparation and quality control of ex tempore preparation and, where appropriate, max. storage time during which each "intermediate product" such as an eluate or finished radiopharmaceutical product "ready for use", conform to its specificationsž. Special instructions are also included relating to the safe container storage (contact package) and unused substance.

This presentation and review of the structure and content of SPC, which is the regulatory established and important document for all drugs that are marketed in RS aims to inform and inspire greater motivation of health professionals, particularly clinical pharmacologists at improving Pharmacotherapeutic procedures in the RS.

\section{CONCLUSIONS}

Good scientific and professional practice in the production of reliable clinical and professional information on medicines provides reliable information about medicines and is a key premise for the proper and safe use of medicines in the prevention, diagnosis, therapy and an improved population health.Key information for healthcare professionals (doctors and pharmacists) of registered drug, according to the law are contained in the summary of product characteristics (SPC), which is harmonized with EU directives and regulations (SPC). Protocol content and structure of the information provided in SPC is established according to the Standard Operating Procedure (SOP) and for all drugs is established a unique set of data at EU level, as required and according to our law. The Agency for Medicines and Medical Devices of Serbia (AMMDS), on the basis of well-established professional documentation based on the medication, in a relatively short time of its existence, invested their professional capacity and with the support of eminent experts made available to the professional public SPC for medical drugs registered in RS that can be found at any time at http://www. alims.gov.rs. On the basis of these regulatory documents and indexed manuals and guides, AMMDS permanently works and makes appropriate publications serving health profes- 
sionals in their daily work for the implementation of a rational, effective and evidence-based pharmacotherapy (National Register of drugs, Pharmacotherapy guide). These manuals contain essential, short, relevant information necessary to make informed decisions and advising customers/patients on the use of medicinal products and are the basis for the establishment of an effective Pharmacy information system on drugs (PIS).

\section{REFERENCES}

1. Pharmacotherapy guide 5; Medicines and Medical Devices Agency of Serbia, 2011

2. Laban-Božlć O., Solarović T., Djukić Lj.: Evropski sistem harmonizacije regulative u oblasti registracije lekova. Zbornik radova seminara Registracija lekova; April 1996, Lepenski Vir. (In Serbia)

3. Originalna regulatorna dokumentacija o lekovima Medicines and Medical Devices Agency of Serbia (In Serbia)

4. National Register of drugs 2014.; Medicines and Medical Devices Agency of Serbia; Belgrade, 2014.

5. Zakon o proizvodnji i prometu lekova; Official gazette SRJ; 18/93 (In Serbia)

6. Zakon o lekovima i medicinskim sredstvima; Official gazette RS, No.84//2004; (In Serbia)

7. GS1 opšti priručnik, GS1 Srbija; Izdanje 10 - GS1 Global User Manuel, 2009.

8. Zakon o lekovima i medicinskim sredstvima; Official gazette.RS, No.30/2010 and 107/2012. (In Serbia)

9. Pravilnik o sadržaju i načinu obeležavanja spoljnog i unutrašnjeg pakovanja leka, dodatnom obeležavanju, kao i sadržaju uputstva za lek; Official gazette.RS,, br. 41/2011 od10.06.2011. godine)

10. ATC Index with DDD s: WHO Collaborating Centre for Drug Statistics Methodology, Oslo, 2014.

11. Commission Directive of 23. July 1991 laying down the principles and guidelines of good manufacturing practice for medicinal products for human use $(91 / 356 / \mathrm{EEC})$

12. A Guideline on Summary of Product Characteristics, Regulatory Guidelines - Vol.2C (October 2005, European commission enterprise and industry directorate - general)

13. International Nonproprietary Names (INN) for Pharmaco substances: Cumul. List No. 9, WHO, Geneva, 1996

14. Pravilnik o sadržaju dozvole za stavljanje leka u promet Official gazette.RS, br. 30/2012 od
10.04.2012.) (In Serbia)

15.British National Formulary (BNF): 66, september 2013.

16. Pravilnik o uslovima, sadržaju dokumentacije i načinu odobrenja izmene ili dopune dozvole za stavljanje leka u promet: Official gazette.RS, No. 30/2012 (In Serbia)

17. Jedinstvena klasifikacija lekova, Savezni zavod za zaštitu i unapredjenje zdravlja, (Glavni i odgovorni urednik T. Baković; CIP katalogizacija u publikaciji Narodna biblioteka Srbije, Beograd, 615.2.001.33; ID =53329932; Elit medica, 1997) (In Serbia)

18. Directive 92/27/EEC (31.03.1992. Council directive on the labelling of medicinal products for human use and on package leafleats, Brussels)

19. Vodič kroz Anatomsko-Terapijsko-Hemijsku (ATC) klasifikaciju lekova registrovanih u SRJ sa dnevnim definisanim dozama (DDD) (Urednik Lj. Djukić; Autori Lj. Djukić, M. Miljković, B. Terzić; II izdanje; CIP Katalogizacija u publikaciji Narodna biblioteka Srbije, Beograd, ISBN 86-82601-03-6, 1999). (In Serbia)

20. Pravilnik o ATC klasifikaciji lekova („Official gazette SRJ, No:3/1-02-001-2002-1) (In Serbia) 


\title{
Dostupnost pouzdanih informacija o lekovima u Srbiji za zdravstvene profesionalce Sažetak Karakteristika Leka
}

\author{
Ljiljana C. Djukić', Branka M. Terzić \\ ${ }^{1}$ Agencija za lekove i medicinska sredstva Srbije, Beograd, Srbija \\ ${ }^{2}$ Klinički Centar Srbije, Beograd, Srbija
}

\section{KRATAK SADRŽAJ}

Uvod Danas su na raspolaganju brojni lekovi za terapiju velikog broja indikacionih područja. Značajna finansijska sredstva se ulažu u istraživanja sa ciljem uvodjenja u terapiju pouzdanih terapeutika. Zato je neophodno obezbediti zdravstvenim profesionalcima egzaktne informacije o novim terapijskim mogućnostima.

Putem brojnih komunikacija putem savremenih informatičkih alata moguć je je sveukupni proces razmene naučnih podataka, ideja i informacija.

Metodologija Prema Zakonu, ključne informacije za zdravstvene profesionalce o registrovanom leku su sadržane u Sažetku karakteristika leka (SKL), koji je usaglašen sa direktivama i regulativom EU (SmPC). Protokol sadržaja i struktura informacija koje su navedene u SKL, utvrdjen je smernicama EU, te je za sve lekove kod nas registrovane uspostavljen jedinstven set podataka. U radu se navode ključni segmenti SKL, sa posebnim osvrtom na opis regulative koja se zahteva za podatke vezane za indikacije, mehanizam delovanja, doziranje, kontraindikacije, neželjena dejstva, interakcije kao i druge važne informacije koje govore o profilu leka, a koje su standardizovane i usaglašene sa strukturom istovetnih dokumenata koji funkcionišu na nivou EU, odnosno EMEA.

Tema U radu se navode ključni segmenti SKL, sa posebnim osvrtom na opis regulative koja se zahteva za podatke vezane za indikacije, mehanizam delovanja, doziranje, kontraindikacije, neželjena dejstva, interakcije kao i druge važne informacije koje govore o profilu leka, a koje su standardizovane i usaglašene sa strukturom istovetnih dokumenata koji funkcionišu na nivou EU, odnosno EMEA.

Zaključak SKL je regulatorno utvrdjen stručni dokument o leku u RS u kome su navedeni naučno dokazani, klinički i farmakoterapijski podaci i informacije o profilu leka, a koji su neophodni za zdravstvene profesionalce-lekare i farmaceute pri sprovodjenju farmakoterapije u našoj sredini. Ovaj dokument je polazna osnova za razvoj primenjene farmakoinformatike koja obuhvata niz aktivnosti značajnih za izradu prikladnih priručnika i stavljanje na raspolaganje podataka i informacija za praćenje indikatora nacionalne politike o lekovima i savremeno lečenje efikasnim lekovima.

Ključne reči: lek, sažetak karakteristika leka, ALIMS 